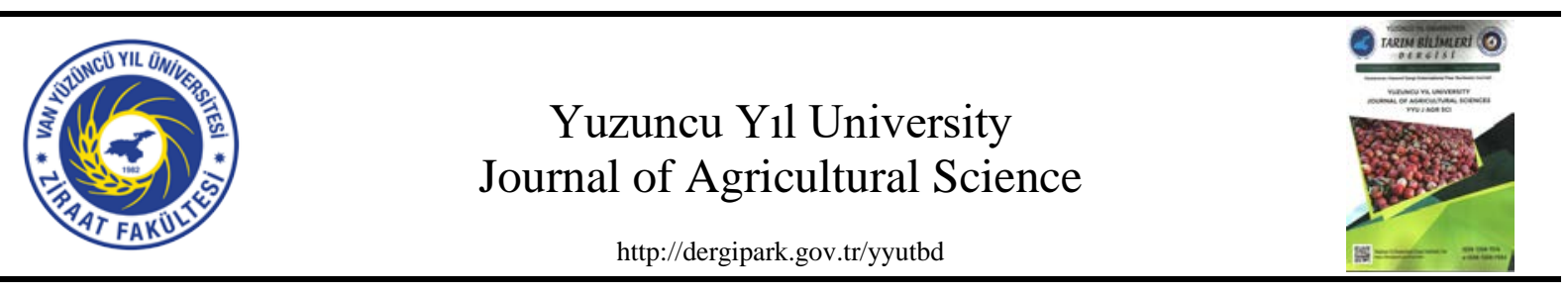

Research Article (Araştırma Makalesi)

Trend Analysis and Comparison of Forecast Models for Production of Turkish Crayfish (Pontastacus leptodactylus Eschscholtz, 1823) in Turkey

\author{
Semih KALE ${ }^{1 *}$, Selçuk BERBER ${ }^{2}$ \\ ${ }^{1}$ Çanakkale Onsekiz Mart University, Faculty of Marine Sciences and Technology, Department of Fishing and \\ Fish Processing Technology, 17020, Çanakkale, Turkey \\ ${ }^{2}$ Çanakkale Onsekiz Mart University, Faculty of Marine Sciences and Technology, Department of Marine and \\ Inland Water Sciences, 17020, Çanakkale, Turkey \\ ${ }^{1}$ https://orcid.org/0000-0001-5705-6935 ${ }^{2}$ https://orcid.org/0000-0003-1123-7217 \\ *Corresponding author e-mail: semihkale@comu.edu.tr
}

\section{Article Info \\ Received: 30.06 .2020 \\ Accepted: 08.12.2020 \\ Online Published 31.12.2020 \\ DOI: 10.29133/yyutbd.761275}

\section{Keywords}

Freshwater crayfish,

Forecast,

Production,

Trend analysis.

\begin{abstract}
This paper aimed to develop forecasting models and to assess the trends in the production of freshwater crayfish in Turkey. Different trend analysis methods (Box-Jenkins method, Şen's innovative trend analysis, MannKendall test) were compared, and different autoregressive integrated moving average (ARIMA) models were generated to forecast the future trend. The results of the innovative trend analysis methodology and ARIMA models revealed that freshwater crayfish production has a decreasing trend during the study period, although there are some fluctuations. ARIMA models predicted that the production of freshwater crayfish would continue to decrease in the future period. The present paper is also the most temporally rich assessment of the crayfish production in Turkey encompassing 100+ years from 1909 to 2018. Several factors such as climate change, overexploitation, diseases, legal regulations, and fisheries management policies might affect the production amount. Therefore, appropriate policies for fisheries management and legal regulations should be planned and implemented to improve the production.
\end{abstract}

\title{
Türkiye’deki Kerevit (Pontastacus leptodactylus Eschscholtz, 1823) Üretimi İçin Trend Analizi ve Tahmin Modellerinin Karşılaştırılması
}

\section{Makale Bilgileri}

Geliş: 30.06 .2020

Kabul: 08.12.2020

Online Yayınlanma 31.12.2020

DOI: 10.29133/yyutbd.761275

\section{Anahtar kelimeler}

Kerevit,

Tahmin,

Üretim,

Trend analizi.
Öz: $\mathrm{Bu}$ çalışmanın amacı Türkiye'deki kerevit üretiminin eğilimlerini değerlendirmek ve geleceğe yönelik tahmin modelleri geliştirmektir. Farklı trend analizi yöntemleri (Mann-Kendall testi, Şen'in yenilikçi trend analizi, Box-Jenkins yöntemi) karşılaştırılmış ve gelecekteki eğilimlerin tahmin edilmesi için farklı otoregresif bütünleşik hareketli ortalama (ARIMA) modelleri geliştirilmiştir. Yenilikçi trend analizi metodolojisinin ve ARIMA modellerinin sonuçları çalışma periyodu boyunca dalgalanmalar olmasına rağmen kerevit üretiminin azalan bir eğilime sahip olduğunu göstermiştir. ARIMA modelleri kerevit üretiminin gelecek dönemlerde azalmaya devam edeceğini tahmin etmektedir. Ayrıca, bu çalışma Türkiye'deki kerevit üretiminin zamansal olarak 1909 ile 2018 y1lları arasındaki 100 y1ldan fazla süreyi kapsayan en geniş değerlendirmesini sunmaktadır. Aşırı avcılık, hastalıklar, iklim değişikliği, yasal düzenlemeler ve balıkçılık yönetimi politikaları gibi birçok faktör üretim miktarını etkileyebilmektedir. Dolayısıyla, üretimin geliştirilmesi için uygun balıkçılık yönetimi politikaları ile yasal düzenlemeler planlanmalı ve uygulanmalıdır. 


\section{Introduction}

Freshwater crayfish, which are the largest forms of decapod crustaceans contain economically important species living in the inland waters, are represented by 737 species and subspecies around the world (Crandall and Buhay, 2008; Crandal and De Grave, 2017). Although it has been reported to be a different subspecies of the species found in Turkey, the species were also reported to be genetically Pontastacus leptodactylus (Akhan et al., 2014). Crayfish production is achieved by both fishing and aquaculture methods. Although the number of species is high, fisheries and aquaculture activities concentrate only on three economically important species (belonging to Cambaridae, Parastacidae, Astacidae).

In Turkey, there are many researches on freshwater crayfish mainly focusing on biology and reproduction (Balık et al., 2005 and 2006; Balik et al., 2005; Berber and Balık, 2006; Berber et al., 2010; Harlioğlu et al., 2012; Bök et al., 2013; Bolat and Kaya, 2016; Harlığlu et al., 2018), population dynamics (Bolat, 2001; Berber et al., 2012; Yüksel et al., 2013), fisheries technology (Balık et al., 2002 and 2003; Bolat et al., 2010), genetic (Akhan et al., 2014), and polyculture (Berber and Kale, 2018; Berber et al., 2019).

Freshwater crayfish stocks should be improved, and alternative production methods should be expanded. The current method of production is based only on the harvesting and is carried out in the form of exploitation of stocks with continuous overfishing pressure without improving the available stocks. In addition to fisheries, freshwater crayfishes are produced in the world by using culture methods. These methods vary depending on the species; it can be listed as a monoculture, alternating, extensive, and intensive. In these production routes, it is aimed to stock up individual or natural stock to natural or artificial reservoirs (Diler, 2013). One of the methods of producing freshwater crayfish is paddy crayfish alternating breeding systems. Researches on the crayfish-rice polyculture are quite limited in Turkey (Berber and Kale, 2018; Berber et al., 2019).

Şen et al. (2019) provided a general description of a trend, as it could be usually directional and in the forms of gradually decreasing or increasing average tendency in a time series. Trends in the time series can be predictable visually. However, methodological and scientific approaches have reasonably limiting assumptions to impartial documentation. Trend analysis aims to forecast the future tendency based on the independent, measurable, and identification, detection systematically, and estimate mechanisms while stochastic element displays itself as the residual nearby the trend (Şen et al., 2019). The detection of trends has great importance and several techniques used for the assessment of trends (Mann, 1945; Kendall, 1955; Sen, 1968, Box and Jenkins, 1976; Şen, 2012; Şen et al., 2019). Trend analysis commonly used in statistical analysis for economical, hydrometeorological, geophysical, environmental, and related time series. Many scientists applied trend analysis to hydrological or climatic time series (Kale et al., 2016a and 2016b and 2018; Ejder et al., 2016a and 2016b; Kale, 2017a and 2017b; Kale and Sönmez, 2018a and 2018b and 2019a and 2019b and 2019c and 2020; Arslan et al., 2020). However, there is no investigation on the assessment of the trends in freshwater crayfish production in Turkey. Therefore, this paper aims to develop forecasting models and to assess the trends in freshwater crayfish production in Turkey.

\section{Material and Methods}

\subsection{Data}

Data used in this study comprises the production amounts of freshwater crayfish (Pontastacus leptodactylus) in Turkey between 1909 and 2018. The data was obtained from Deveciyan (2011) and the website of Turkish Statistical Institute (TurkStat, 2020).

\subsection{Change point analysis}

The change point analysis is a non-parametric test, and it was firstly developed by Pettitt (1979) in order to identify significant variations in the averages of a time series. Change point analysis was executed by using R statistical software (R Core Team, 2020). 
The null hypothesis is that the parameters follow distributions that have a similar position parameter and describes the non-appearance of change point, contrary to the alternative hypothesis that directs the occurrence of a change point. The formulae are given below:

$$
\begin{gathered}
K_{T}=\max \left|U_{t, T}\right| \text {, and for } t=2, \ldots \ldots, T ; \\
U_{t, T}=\sum_{i=1}^{t} \sum_{j=t+1}^{T} \operatorname{sgn}\left(x_{i}-x_{j}\right)
\end{gathered}
$$

The null hypothesis is calculated with $K_{T}$ and $U_{t, T}$ confirms if two samples $\left(x_{1}, \ldots, x_{t}\right.$ and $\left.x_{t}+1, \ldots, x_{T}\right)$ are in the same population. Associated probability $(p)$ is used to compute the level of significance.

\subsection{Trend analysis}

\subsubsection{Box and Jenkins method}

Trend analysis is a frequently applied technique to define the trend in a hydrologic time series. Box and Jenkins (1976) suggested a technique to discovery the best fit of a time-series model to chronological values of a time series, and defined it as autoregressive integrated moving average (ARIMA) model. This technique was implemented in order to determine the trend in the streamflow data. Trend analyses were executed in SPSS and Minitab statistical software. In addition, autocorrelation analyses were performed to calculate the consistency of trend analysis results. The used ARIMA model is as follow:

$$
X_{t}=c+\Phi_{1} X_{t-1}+\cdots+\Phi_{p} X_{t-p}+\theta_{1} e_{t-1}+\theta_{q} e_{t-q}+e_{t}
$$

Herein, $X_{t}$ is the variable will be defined in $t$ time, $e_{t}$ is the error in $t$ time, $\theta$ is the coefficient of per $q$ parameter, $\Phi$ is the coefficient of per $p$ parameter, and $c$ is the constant.

Primarily, the order of differencing and grades of the AR and MA were determined by using autocorrelation function (ACF) and partial autocorrelation function (PACF). Then, the parameters were anticipated to check the residuals are white noise. In the last stage, the best-fit model was reached over residuals analysis. Ljung-Box test statistic was used to approve the randomness. Normalized Bayesian Information Criterion (BIC), R-squared, and $p$ values were compared. ARIMA model with minimum normalized BIC, $p$ and R-squared values were chosen as the best fit model and used to estimate. The precision of models was evaluated by using frequently used performance measures which are root mean square error (RMSE), mean absolute error (MAE), and mean absolute percentage error (MAPE).

\subsubsection{Innovative trend analysis method}

Innovative trend analysis methodology was firstly proposed by Şen (2012). In this method, dataset in the time series is firstly sorted from the past to the recent date, and then it is divided into two equivalent halves. Both sets are independently sorted again in ascending order. Plotting is carried out on the Cartesian coordinate system. The first part of the time series is positioned on the horizontal $X$ axis, and the other part is positioned on the vertical $Y$-axis. If data are plotted on the $1: 1\left(45^{\circ}\right)$ line, it indicates that there is no trend. On the other hand, if data are located on the lower/upper area of the 1:1 line, it indicates that there is decreasing/increasing trend in given time series (Şen, 2012 and 2014). The null hypothesis of this method is that there is no statistically significant decreasing/increasing trend. Otherwise, the alternative hypothesis is the existence of a statistically significant decreasing/increasing trend in the given time series. Şen's innovative trend analysis methodology was commonly implemented to hydroclimatological time series observed at different locations through the 
world (Şen, 2014 and 2015; Kişi et al., 2015; Ay et al., 2018; Gedefaw et al., 2018; Alifujiang et al., 2020).

\subsubsection{Mann-Kendall and Spearman's Rho Test}

Mann-Kendall test was initially suggested by Mann (1945), and then it was advanced by Kendall (1955). The Mann-Kendall test is a comprehensively accomplished test to examine a trend in a time series. One advantage of this non-parametric test is that the data do not require to track any specific distribution. The formulae are given below:

$$
S=\sum_{i=1}^{n-1} \sum_{k=i+1}^{n} \operatorname{sgn}\left(x_{k}-x_{i}\right)
$$

In this formula, the time series $x_{i}$ is from $i=1,2, \ldots, n-1$, and $x_{k}$ from $k=i+1, \ldots, n$.

$$
\operatorname{sgn}(\theta)=\left\{\begin{array}{rr}
+1, & \theta>0 \\
0, & \theta=0 \\
-1, & \theta=0
\end{array}\right.
$$

Normalized test statistic is calculated by the next equation:

$$
Z_{c}= \begin{cases}\frac{S-1}{\sqrt{\operatorname{var}(S)},} & S>0 \\ \frac{S+1}{\sqrt{\operatorname{var}(S)},}, & S<0\end{cases}
$$

In this formula, the test statistic is $Z_{c}$ and when $\left|Z_{c}\right|>Z_{1-\alpha / 2}$, in which $Z_{1-\alpha / 2}$ are the standard normal variables, and $\alpha$ is the significance level for the test, $H_{0}$ will be rejected. The size of the trend is calculated by the formula given below:

$$
\beta=\operatorname{Median}\left(\frac{x_{i}-x_{j}}{i-j}\right), \forall_{j}<i, \text { where } 1<j<i<n \text {. }
$$

A positive value of $\beta$ points to an increasing trend, while a negative value of $\beta$ points to a decreasing trend.

Non-parametric Spearman's rho test was carried out to compute the strength of a monotonic relationship between two parameters (Lehmann, 1975; Sneyers, 1990). Non-parametric Spearman's rho test and Mann-Kendall test suggest more truthful outcomes than parametric tests (Kale and Sönmez, 2018a).

\section{Results}

Pre-whitening processes were not implemented to the data, and original raw data was used to keep the originality of the time series in the trend analysis methodology. Table 1 describes the basic statistics of the time series. The results of the Mann-Kendall and Spearman's rho tests were provided in Table 2. The number of available data is 62 . 
Table 1. Descriptive statistics of time series data

\begin{tabular}{lcccccccc}
\hline Period & Mean & SE & SD & CS & CV & CK & Min & Max \\
\hline First half & 2270.97 & 463.20 & 2578.97 & 2.12 & 1.14 & -0.63 & 3 & 7937 \\
Second half & 949.58 & 101.03 & 535.51 & 3.67 & 0.59 & 0.11 & 320 & 2317 \\
All data & 1610.27 & 249.85 & 1967.31 & 2.04 & 1.22 & 2.56 & 3 & 7937 \\
\hline
\end{tabular}

Note: SE is the standard error, SD is the standard deviation, CS is the coefficient of skewness, CV is the coefficient of variation, CK is the coefficient of kurtosis, Min is the minimum value, and Max is the maximum value.

The normality of the dataset was analysed by Shapiro-Wilk and Kolmogorov-Smirnov tests. In these tests, the null hypothesis is that the sample data are not significantly different from a normal population. On the other hand, the alternative hypothesis is that the data are meaningfully different from a normal population. The statistics of the normality tests were found 0.699 and 0.265 by ShapiroWilk test and Kolmogorov-Smirnov test (with Lilliefors significance correction). The $p$-values for both tests were found 0.00 . The results of the normality test exhibited that these data are significantly different from normal. Therefore, non-parametric Spearman's rank correlation and Mann-Kendall test tests were implemented to the dataset. The results of the tests were given in Table 2. In addition, Sen's slope value was calculated as 6.952381.

Table 2. The results of the non-parametric tests

\begin{tabular}{lll}
\hline Statistical parameters & Values & Trend \\
\hline Kendall's tau & 0.100 & $\mathbf{\nabla}$ \\
$p$ & 0.251 & \\
Spearman's rho & 0.148 & $\mathbf{\nabla}$ \\
$p$ & 0.251 & \\
\hline
\end{tabular}

Note: $\boldsymbol{\nabla}$ indicates statistically insignificant decreasing trend

Change point analysis results stated that the change point of the time series was 1967. On the other hand, one more analysis was performed for further understanding the trends and patterns in the freshwater crayfish production by using a specific part of the time series covering the period from 1965 to 2018 since the production amounts regularly recorded at this period. The results of this analysis directed to 1988 as the change point. After 1988, the production amount fell by half year by year. The main reason for this decrease was the crayfish plague.

Şen's innovative trend test result is presented in Figure 1. The results of the innovative trend analysis methodology revealed that freshwater crayfish production in Turkey has a monotonic decreasing trend. 


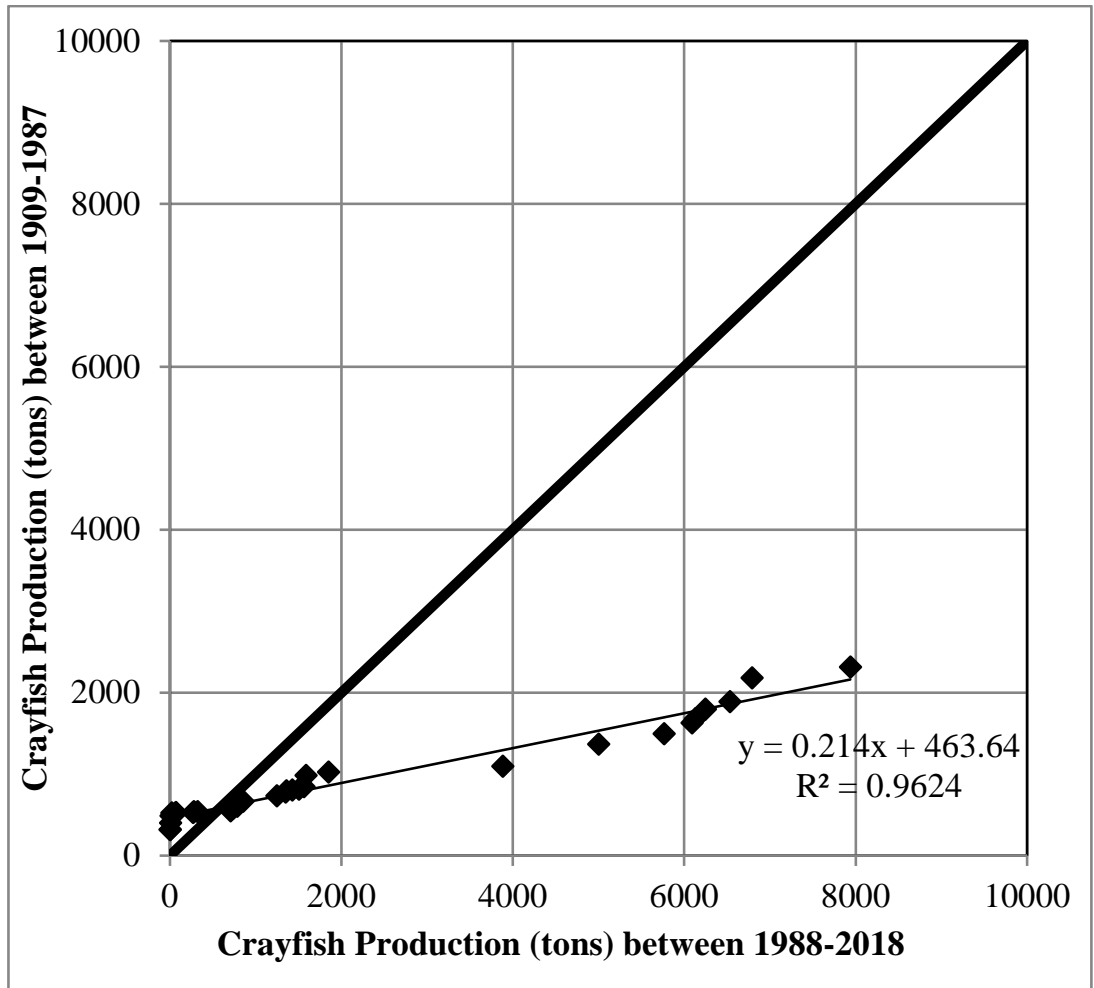

Figure 1. Scatter diagram of freshwater crayfish production in Turkey according to the Şen's innovative trend analysis method.

Box and Jenkins (1976) recommended that the practice of the autocorrelation function (ACF) and the partial autocorrelation function (PACF) as the main analyses to decide the model sequence of ARIMA. The results of ACF and PACF of ARIMA (1,1,1), ARIMA (2,1,2), ARIMA $(0,1,1)$, ARIMA $(1,0,1)$, and ARIMA $(1,1,0)$ models were presented in Figure 3, Figure 5, Figure 7, Figure 9, and Figure 11, respectively. The best fitted model is the model over and done with random residuals at a certain significance level. Henceforth, the level of significance of ARIMA models was compared. In addition, Ljung-Box test statistic was performed to approve the randomness. The values of R-squared were deliberated to choose the best fitted model. Values of R-squared that closer to zero and lower values of normalized Bayesian Information Criterion (BIC) demonstrate a good fit. Therefore, ARIMA $(0,1,1)$ model was chosen to estimate the future trends of the freshwater crayfish production in Turkey. The precision of models was evaluated by using frequently used performance measures which are root mean square error (RMSE), mean absolute error (MAE), and mean absolute percentage error (MAPE) (Table 3).

Time series plots and future predictions of different ARIMA models were illustrated in Figure 2, Figure 4, Figure 6, Figure 8, and Figure 10. Upper confidence limits, lower confidence limits, fit and forecast values were also demonstrated in these figures. ARIMA $(1,0,1)$ model predicted a statistically significant increasing trend in the production amount of freshwater crayfish, while other ARIMA models predicted a decreasing trend. ARIMA $(1,1,1)$ model pointed out that the decreasing trend in the production amount of freshwater crayfish was found statistically insignificant whereas the decreasing trend was found statistically significant by ARIMA $(0,1,1)$, ARIMA $(1,0,1)$, and ARIMA $(2,1,2)$ models. 


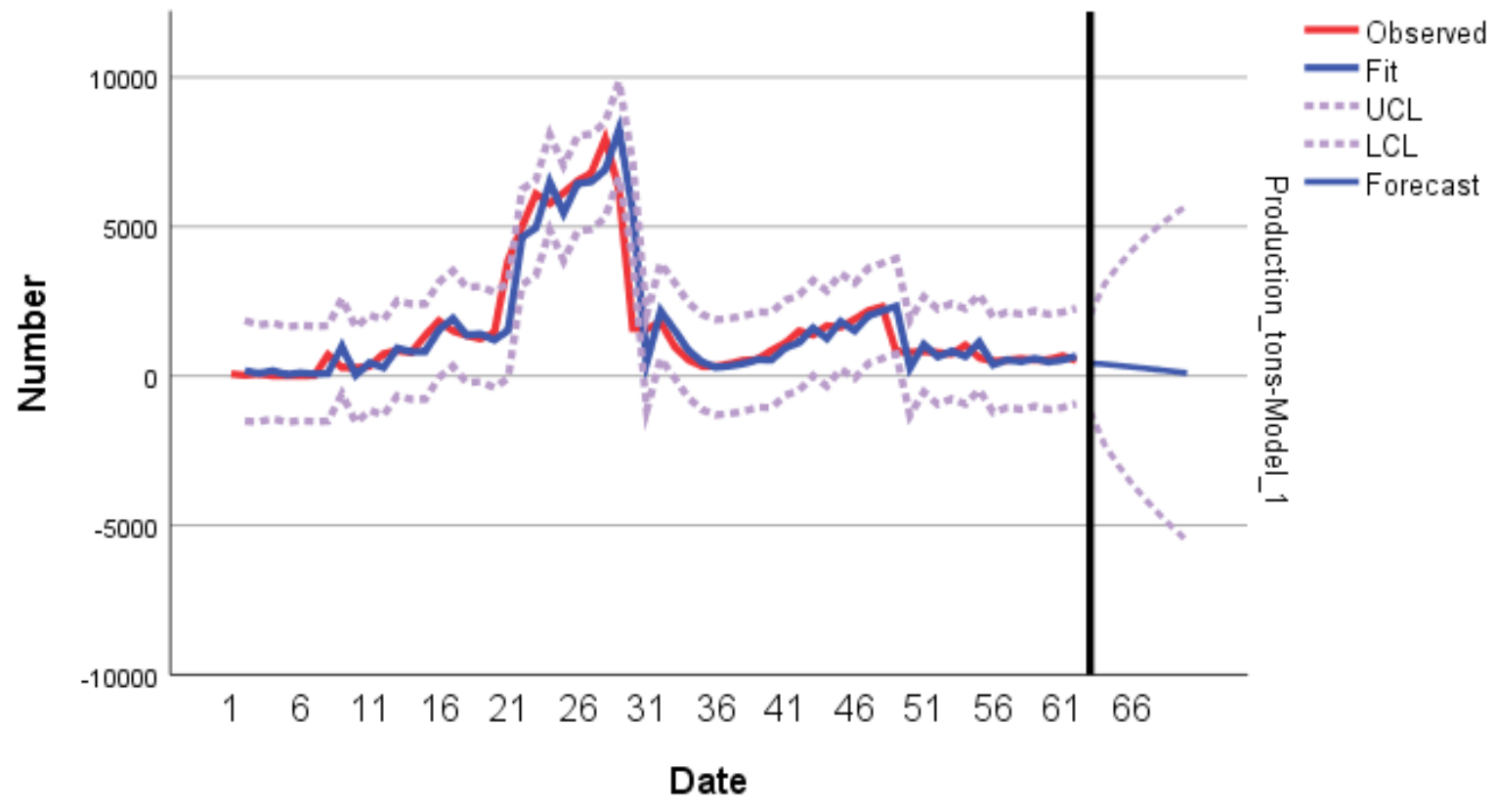

Figure 2. Output of ARIMA $(1,1,1)$ model for freshwater crayfish production in Turkey.

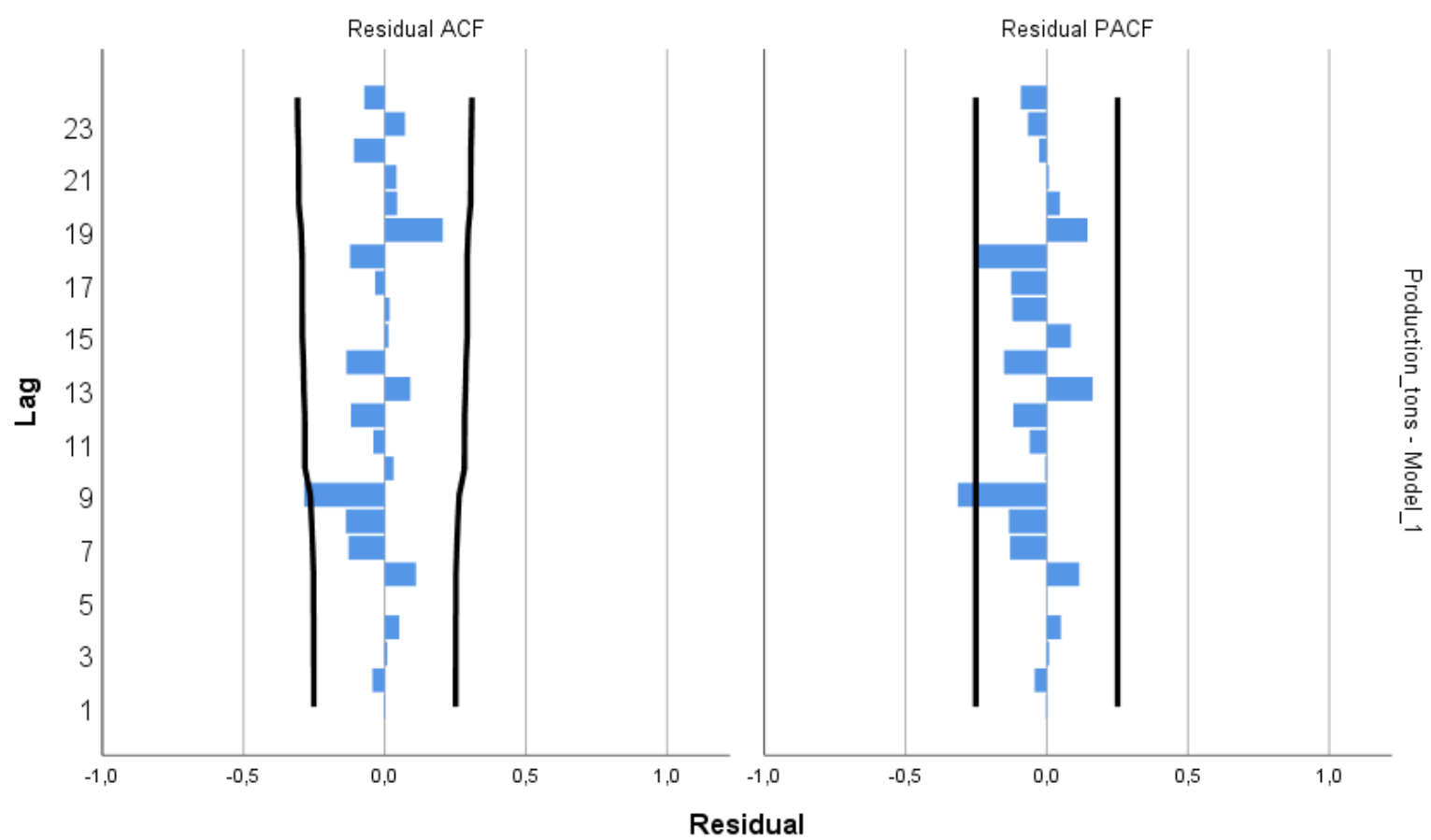

Figure 3. Residuals of autocorrelation functions and partial autocorrelation functions of ARIMA $(1,1,1)$ model for freshwater crayfish production in Turkey 


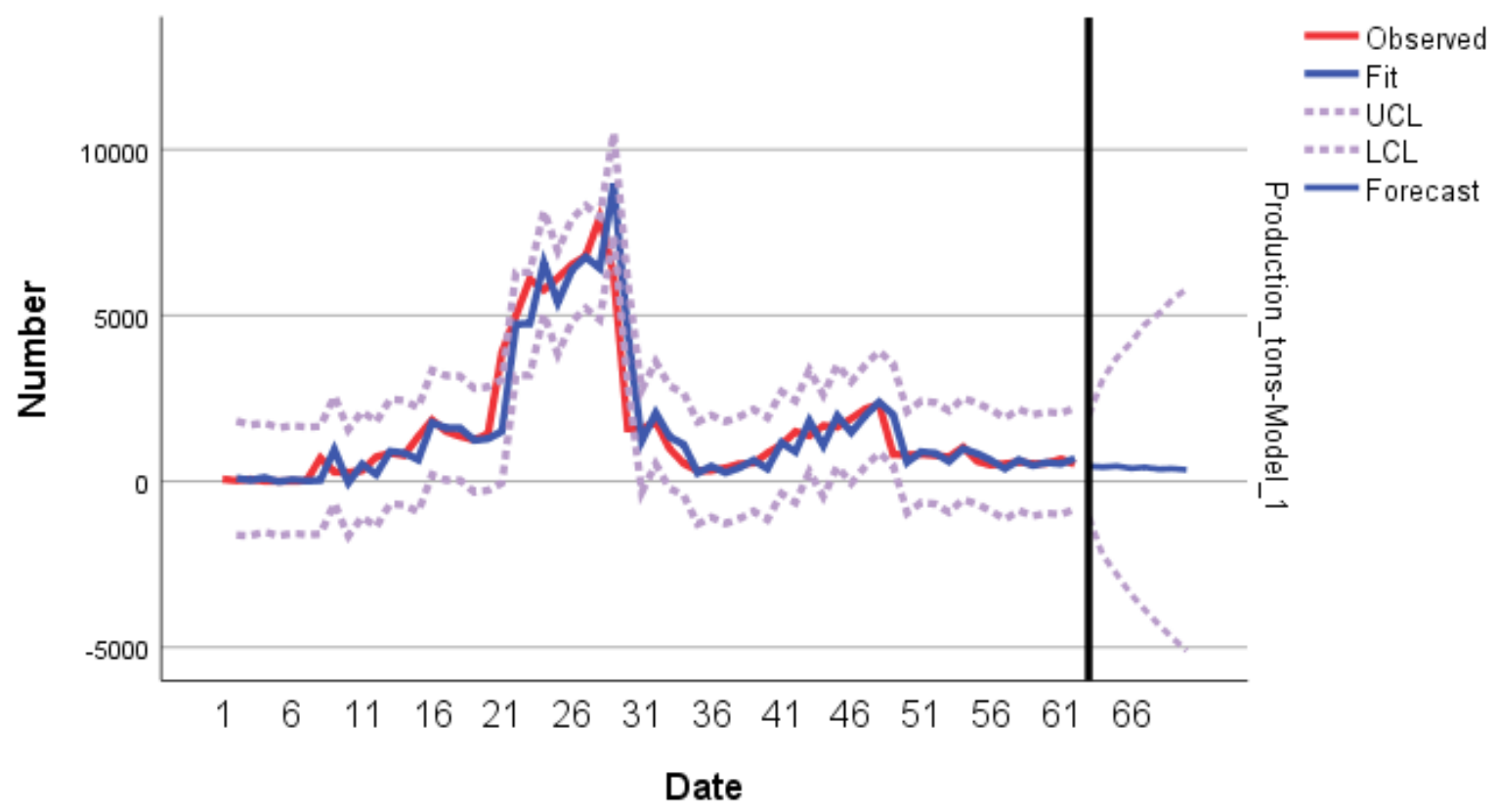

Figure 4. Output of ARIMA $(2,1,2)$ model for freshwater crayfish production in Turkey.

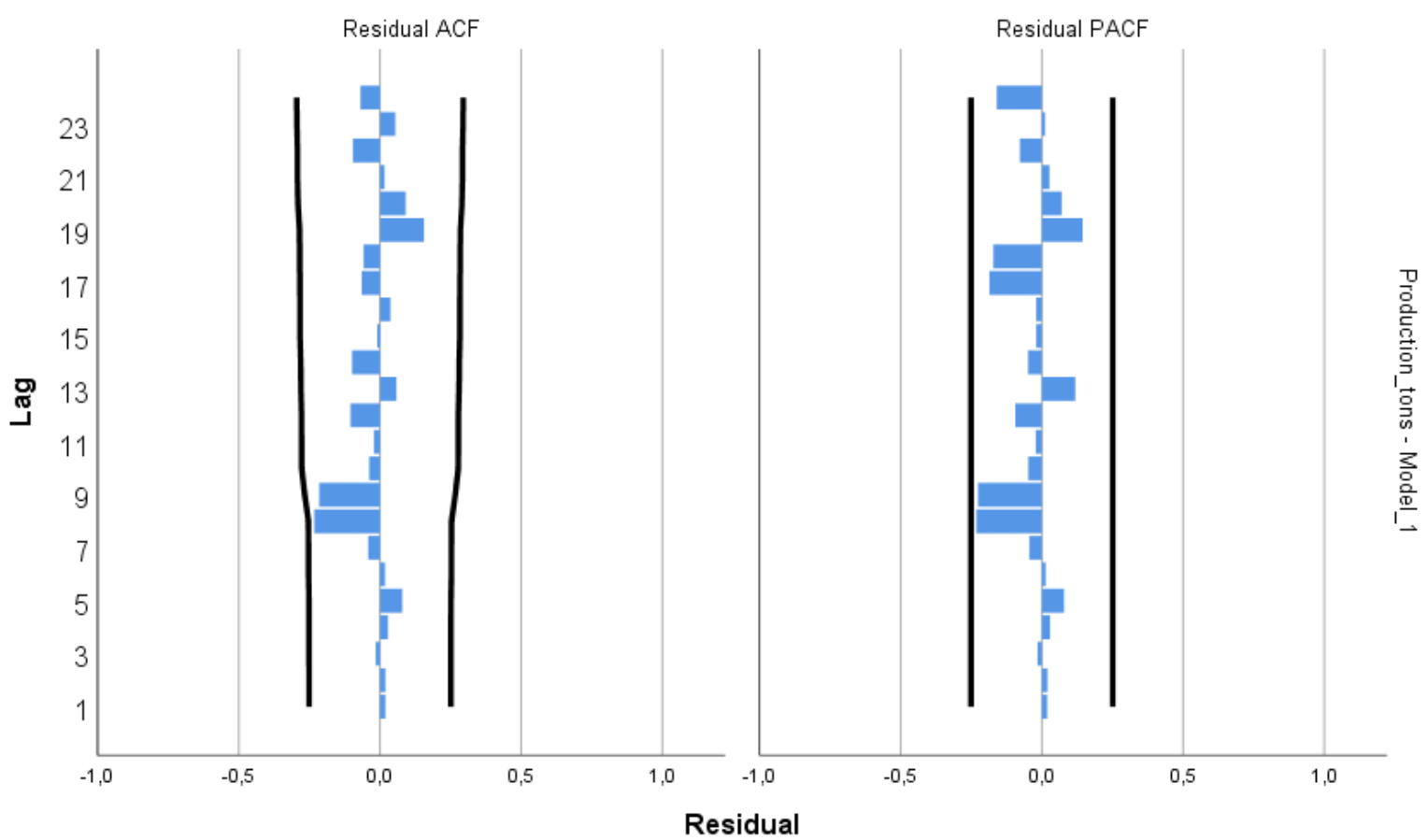

Figure 5. Residuals of autocorrelation functions and partial autocorrelation functions of ARIMA $(2,1,2)$ model for freshwater crayfish production in Turkey. 


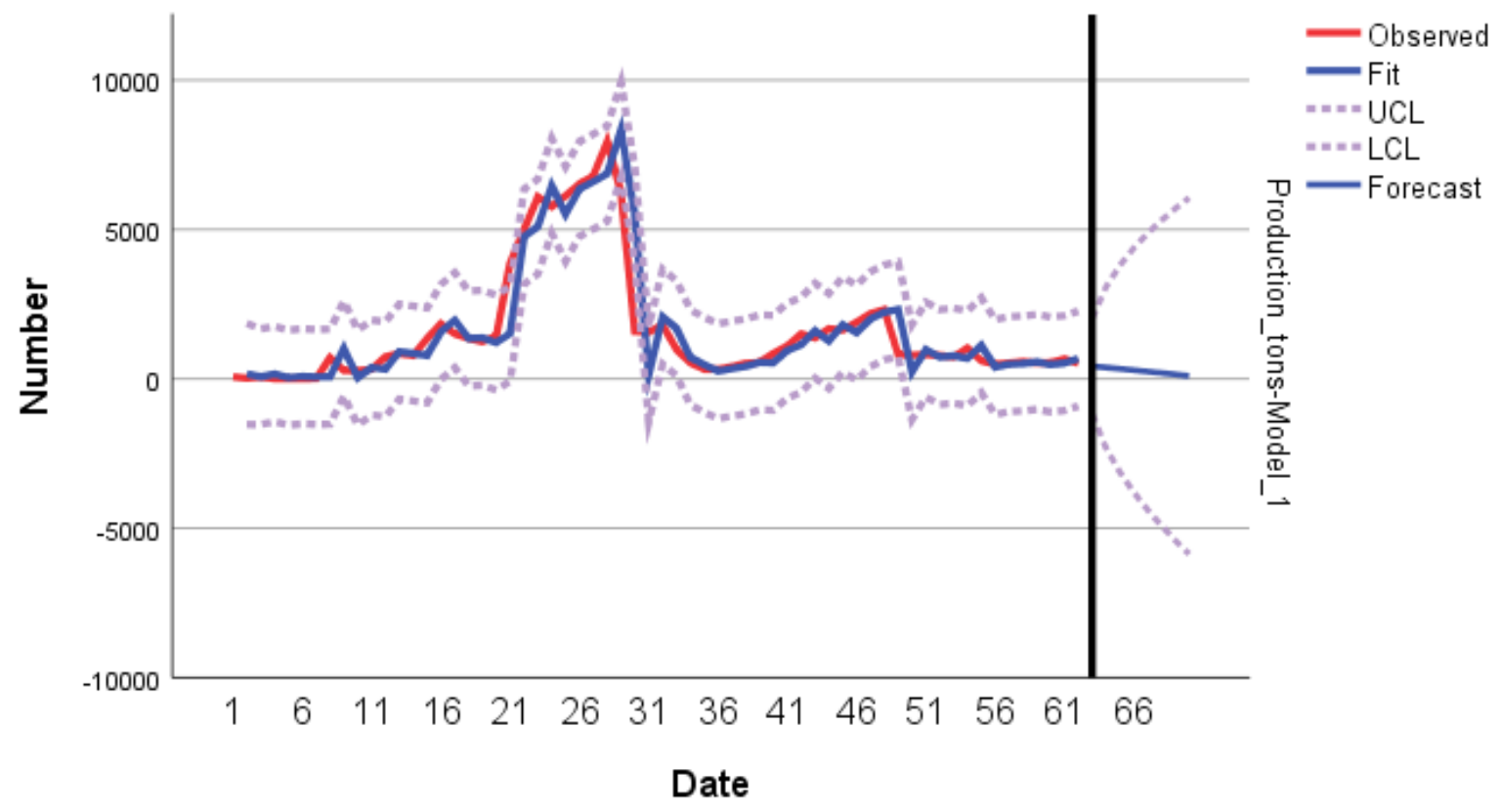

Figure 6. Output of ARIMA $(0,1,1)$ model for freshwater crayfish production in Turkey.

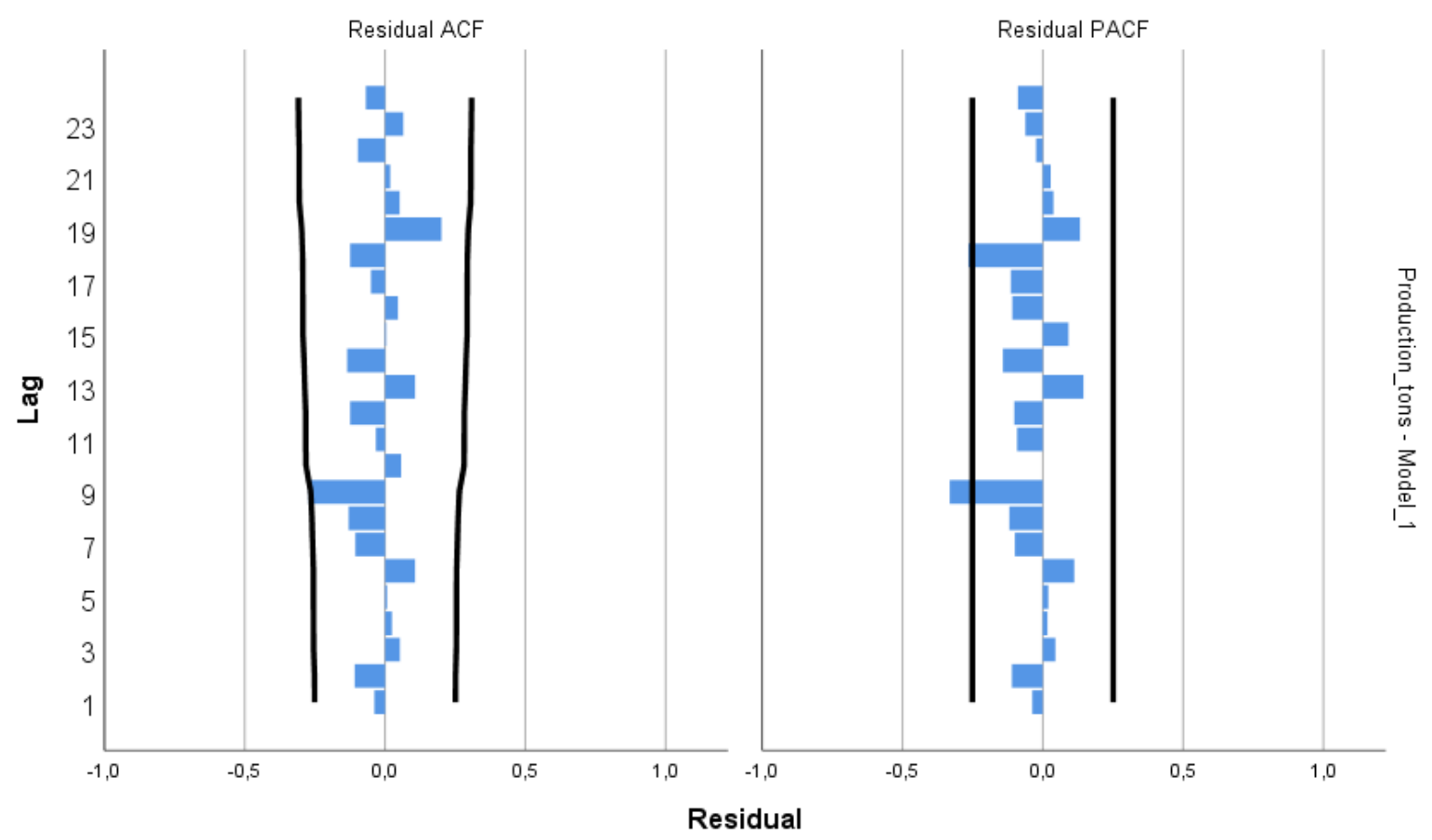

Figure 7. Residuals of autocorrelation functions and partial autocorrelation functions of ARIMA $(0,1,1)$ model for freshwater crayfish production in Turkey 


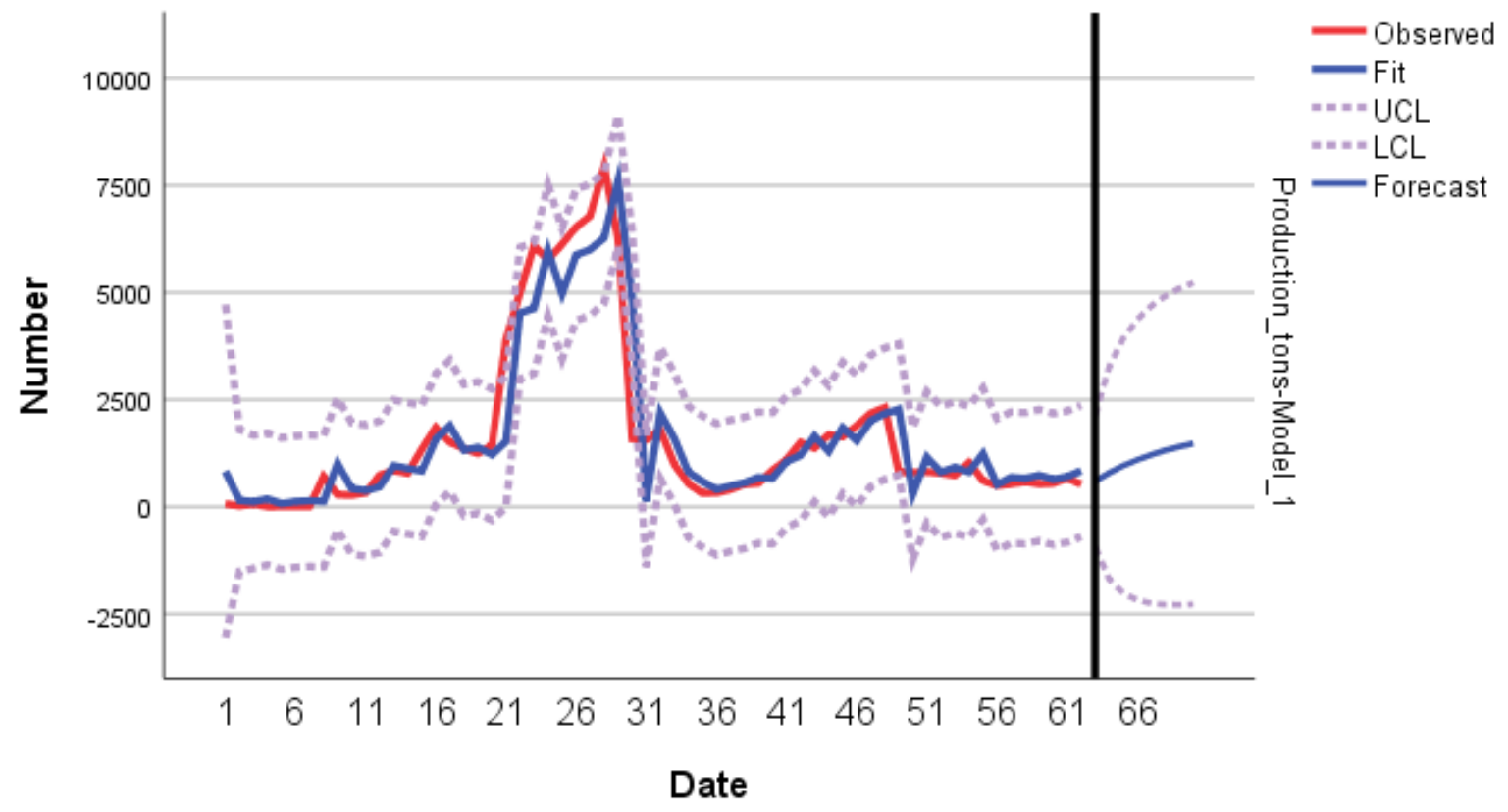

Figure 8. Output of ARIMA (1,0,1) model for freshwater crayfish production in Turkey.

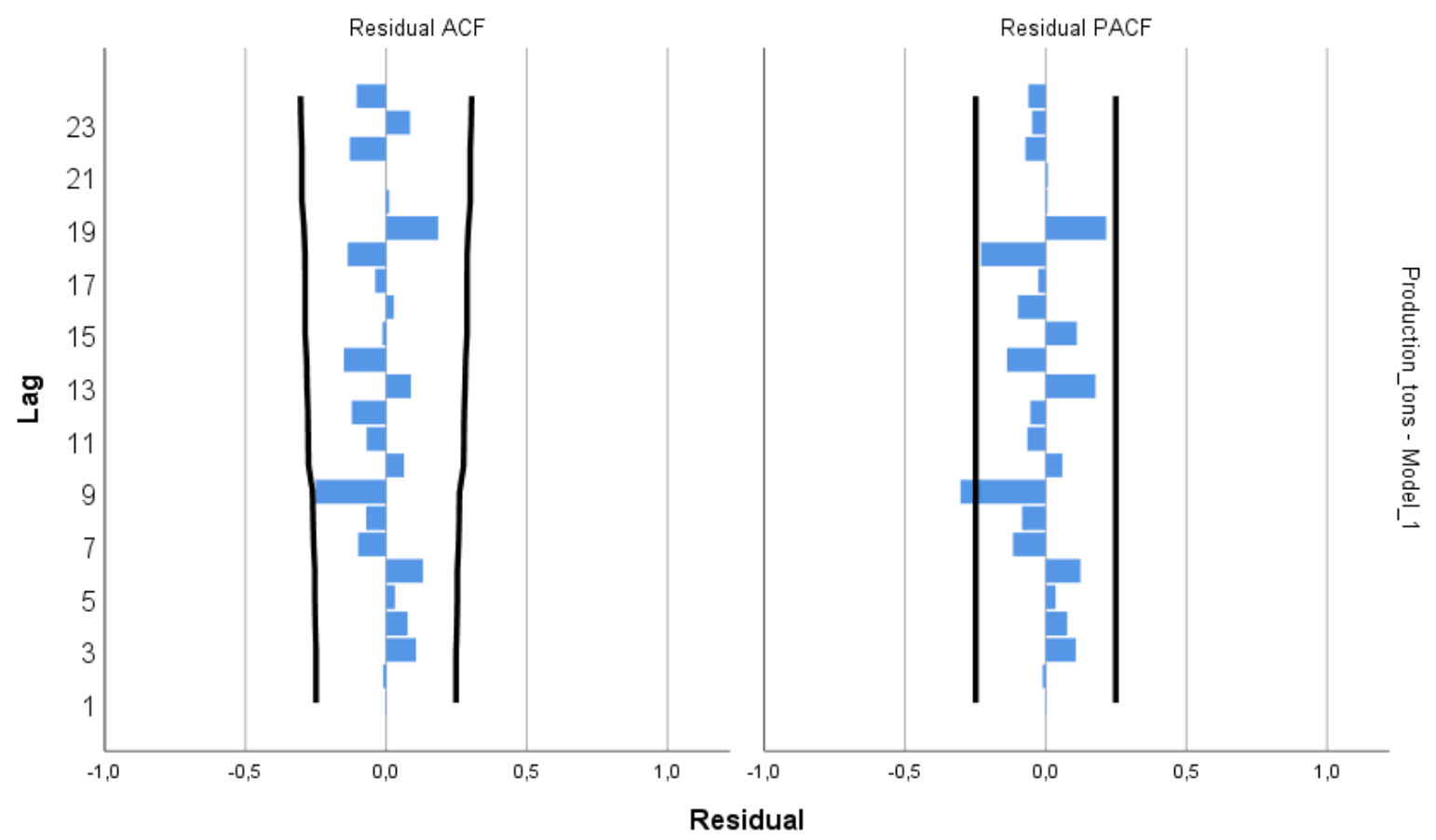

Figure 9. Residuals of autocorrelation functions and partial autocorrelation functions of ARIMA $(1,0,1)$ model for freshwater crayfish production in Turkey. 


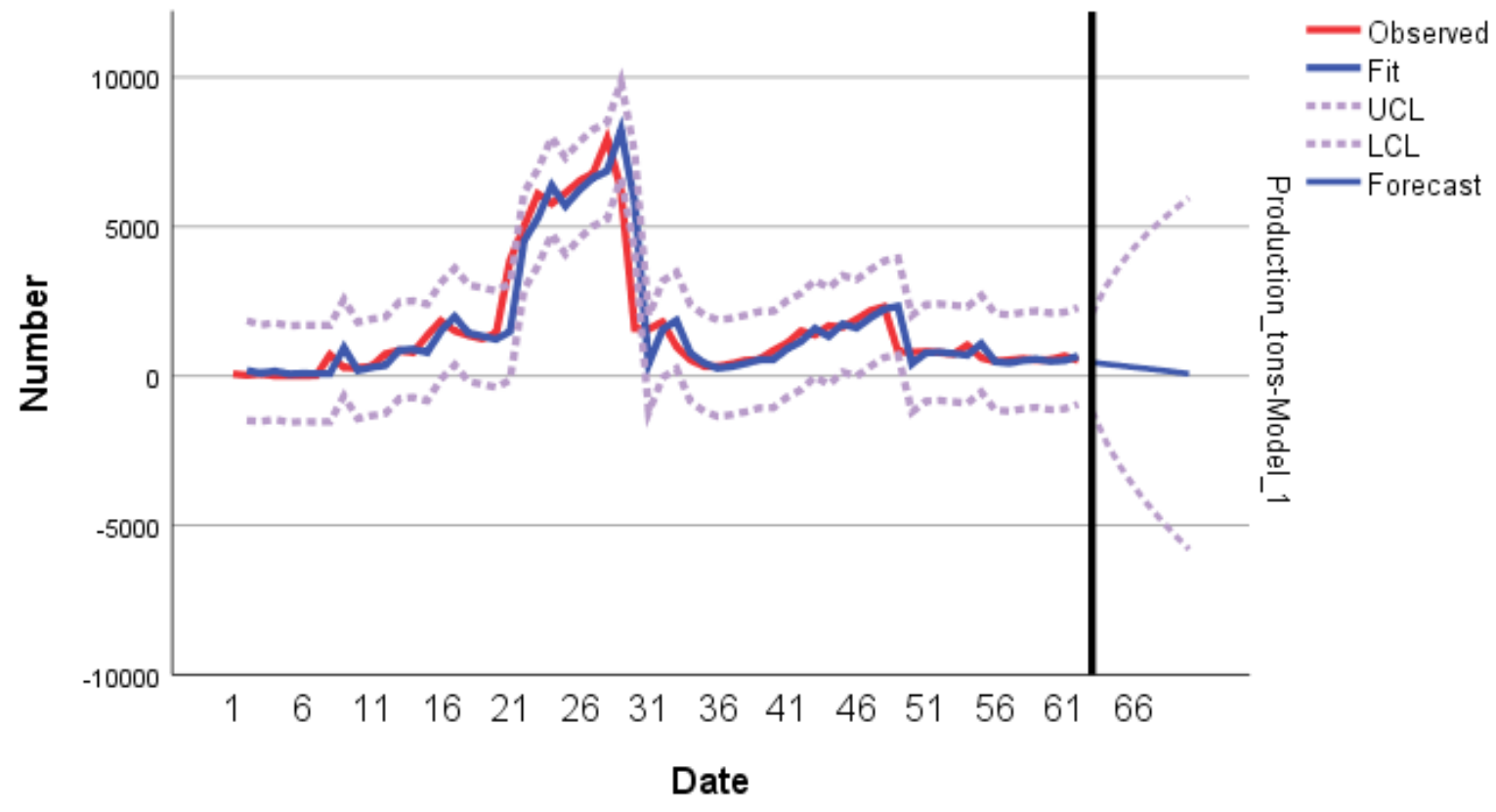

Figure 10. Output of ARIMA $(1,1,0)$ model for freshwater crayfish production in Turkey.

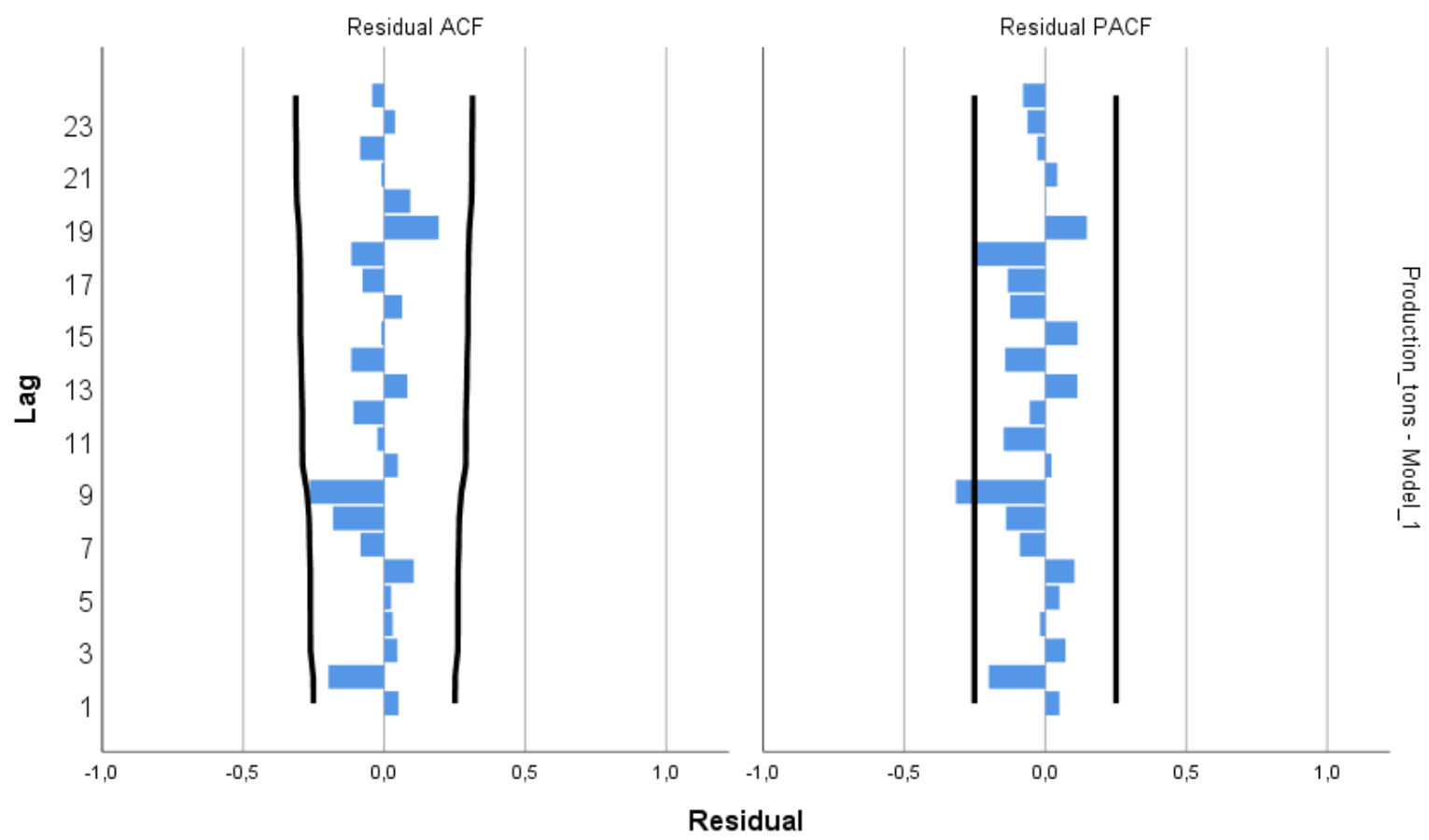

Figure 11. Residuals of autocorrelation functions and partial autocorrelation functions of ARIMA $(1,1,0)$ model for freshwater crayfish production in Turkey.

The production of freshwater crayfish gradually increased from 1908 (the first recorded time of the crayfish production) until 1985. A disease titled crayfish plague occurred in 1985 and the production was suddenly ground to a halt. Crayfish plague is an infectious fungal disease affecting freshwater crayfish. The occurrence of the plague has caused the closure of fisheries in the Eğirdir Lake Basin and Burdur Lake Basin. 
Table 3. Parameters of ARIMA models for predicting of freshwater crayfish production in Turkey

\begin{tabular}{|c|c|c|c|c|c|c|c|c|c|c|}
\hline \multirow{3}{*}{$\overbrace{\text { Parameters }}^{\text {Models }}$} & \multirow{3}{*}{$\begin{array}{c}\text { ARIMA }(1,1,0) \\
A R\end{array}$} & \multirow{3}{*}{$\begin{array}{c}\text { ARIMA }(0,1,1) \\
M A\end{array}$} & \multicolumn{2}{|c|}{ ARIMA $(1,1,1)$} & \multicolumn{4}{|c|}{ ARIMA $(2,1,2)$} & \multicolumn{2}{|c|}{ ARIMA $(1,0,1)$} \\
\hline & & & \multirow{2}{*}{$A R$} & \multirow{2}{*}{$M A$} & \multicolumn{2}{|c|}{$A R$} & \multicolumn{2}{|c|}{$M A$} & \multirow{2}{*}{$A R$} & \multirow{2}{*}{$M A$} \\
\hline & & & & & Lag1 & $\operatorname{Lag} 2$ & Lag1 & $\operatorname{Lag} 2$ & & \\
\hline$\overline{\text { Coefficient }}$ & 0.253 & -0.367 & -0.224 & -0.554 & -1.402 & -0.561 & -1.855 & -0.999 & 0.838 & -0.437 \\
\hline SE of coefficient & 0.127 & 0.123 & 0.343 & 0.294 & 0.128 & 0.132 & 1.640 & 1.766 & 0.075 & 0.129 \\
\hline$p$-value & 0.051 & 0.004 & 0.516 & 0.758 & 0.000 & 0.000 & 0.263 & 0.574 & 0.000 & 0.001 \\
\hline Normalized BIC & 13.590 & 13.557 & \multicolumn{2}{|c|}{13.631} & \multicolumn{4}{|c|}{13.704} & \multicolumn{2}{|c|}{13.562} \\
\hline $\mathrm{R}^{2}$ & 0.838 & 0.843 & \multicolumn{2}{|c|}{0.845} & \multicolumn{4}{|c|}{0.860} & \multicolumn{2}{|c|}{0.854} \\
\hline RMSE & 807.405 & 794.066 & \multicolumn{2}{|c|}{796.920} & \multicolumn{4}{|c|}{772.478} & \multicolumn{2}{|c|}{771.114} \\
\hline MAPE & 181.472 & 172.505 & \multicolumn{2}{|c|}{185.721} & \multicolumn{4}{|c|}{117.929} & \multicolumn{2}{|c|}{233.100} \\
\hline MAE & 410.889 & 421.529 & \multicolumn{2}{|c|}{430.202} & \multicolumn{4}{|c|}{410.249} & \multicolumn{2}{|c|}{452.196} \\
\hline Ljung-Box Statistics & 16.646 & 15.126 & \multicolumn{2}{|c|}{14.700} & \multicolumn{4}{|c|}{10.886} & \multicolumn{2}{|c|}{14.496} \\
\hline Ljung-Box $p$-value & 0.479 & 0.586 & \multicolumn{2}{|c|}{0.547} & \multicolumn{4}{|c|}{0.695} & \multicolumn{2}{|c|}{0.562} \\
\hline
\end{tabular}

\section{Discussion and Conclusion}

Seafood has global importance to human nutrition and is the most traded food commodity (Gephart et al., 2017). Unexpected interruptions or shocks for food production may harmfully affect the trade and admission to food commodities. The trends and patterns of shocks to aquaculture and fisheries are poorly considered, and therefore it restricts the capability to generalize or forecast reactions to environmental, economic, and political changes.

There are different methods to forecast the trends in any time series. A frequently used Spearman's rho and Mann-Kendall tests have some limiting assumptions. Kişi (2015) indicated those restrictive assumptions as of the length of the data, normal distribution, and independent structure of the time series. Trend analysis was commonly applied to hydrometeorological time series by many scientists (Kale et al., 2016a and 2016b and 2018; Ejder et al., 2016a, and 2016b; Kale, 2017a, and 2017b; Kale and Sönmez, 2018a and 2018b and 2019a, and 2019b and 2019c; Sönmez and Kale, 2020, Arslan et al., 2020). Likewise, Şen's innovative trend analysis methodology was also frequently applied to hydroclimatological time series observed at different locations through the world (Şen, 2014 and 2015; Kişi et al., 2015; Ay et al., 2018; Gedefaw et al., 2018; Alifujiang et al., 2020).

Gephart et al. (2017) documented shocks to fish production, and they noted identification, trends, and consequences of fish production in detail. Recent trends in the production of fisheries resources have been investigated by several studies. For instance, Srivastava (2004) investigated the latest trends in export and production of fish in India. The authors examined the temporal production of fish and noted that marine and inland fish production in India significantly grew over time. Moreover, the authors indicated that the comparatively higher growth of inland fish production point out that aquaculture is being deliberated as the employment for avocation generating and promising income for local people. Karimpour et al. (2011) investigated the status of freshwater crayfish in Iran. Oladimeji (2017) examined the trend in the production of fish in Nigeria from 1970-2014. The author indicated that the estimated demand for fish develops faster than variation in local fish production. Correspondingly, Oladimeji (2018) examined the trend of artisanal fisheries production in Nigeria and documented that demand for fish products and gross domestic product of Nigeria progressively increased during the study period, while the domestic production of fish commodity and other agricultural products fluctuates. In addition, the author put forward that there was no interconnection between either aquaculture or artisanal fisheries production and economic growth from 1970 to 2014 .

In Turkey, there are few reports on the current status of the freshwater crayfish (Harlioglu and Holdich, 2004; Harlıoğlu and Harlıoğlu, 2004 and 2009; Harlioğlu, 2008; Aydin et al., 2012; Türel et al., 2015; Cilbiz et al., 2020; Berber, 2020). In addition, Kale et al. (2020) documented the first report of the albinism in P. leptodactylus and Kale et al. (2021) reported blue color anomaly in $P$. leptodactylus from Atikhisar Reservoir, Çanakkale. These anomalies attributed to genetic recessive 
due to lack of melanin and carotenoid pigments. Berber et al. (2014) documented problems and solutions for ensuring the sustainability of crayfish stocks in terms of fisheries management. On the other hand, there is no study on the assessment of trends and patterns of the freshwater crayfish production. The present paper is the first study on the future forecasting and the assessment of the trends in the freshwater crayfish production in Turkey. Moreover, this is the most temporally rich assessment of the crayfish production in Turkey encompassing 100+ years from 1909 to 2018.

Freshwater crayfish stocks should be enhanced, and alternative production approaches should be considered. The current method of production is only depending on the harvesting and is conducting by the exploitation of stocks with continuous overfishing pressure without improving the existing resources. Similarly, Cilbiz et al. (2020) noted that available freshwater crayfish stocks are encountered some problems such as habitat destruction, aquatic pollution, fishing pressure and disease. Therefore, the production of freshwater crayfish by only harvesting the natural stocks has no potential to be increased in the future period. Hence, investigations on monoculture or polyculture (e.g., suggested by Berber and Kale, 2018; Berber et al., 2019) of freshwater crayfish should be progressively carried out. Berber and Kale (2018) suggested the rice-crayfish polyculture as an alternative, applicable, and economic approach to growth crayfish with rice production. Berber et al. (2019) determined the ideal stock density of freshwater crayfish in polyculture with rice. Limited studies on polyculture of crayfish and rice revealed that crayfish polyculture with rice production in paddy fields are successfully accomplished in Turkey. Therefore, rice-crayfish polyculture can be applied due to the abundance of paddy fields in Turkey. Thus, the increase in the production of freshwater crayfish can increase the income level of relevant people and also it may provide employment opportunities, economic growth, and social welfare. Artisanal fisheries and sport fishing activities could be more attractive in such water bodies allowing self-fishing in the water resources.

In conclusion, this paper assessed the trends in the production of freshwater crayfish in Turkey. Moreover, different trend analysis methods and forecasting models were compared. The present paper is also the most temporally rich assessment of the crayfish production in Turkey encompassing 100+ years from 1909 to 2018. The results of the innovative trend analysis methodology and ARIMA models revealed that freshwater crayfish production has a decreasing trend during the study period, although there are some fluctuations. ARIMA models predicted that the production of freshwater crayfish would continue to decrease in the future period. Several factors such as climate change, overexploitation, diseases, legal regulations, fisheries management policies might affect the production amount. Therefore, appropriate policies for fisheries management and legal regulations should be planned and implemented to improve the production.

\section{Acknowledgements}

The authors would like to thank all staff of the Turkish Statistical Institute (TÜIK) for the efforts in data collecting and making them available.

\section{References}

Akhan, S., Bektas, Y., Berber, S., \& Kalayci, G. (2014). Population structure and genetic analysis of narrow-clawed crayfish (Astacus leptodactylus) populations in Turkey. Genetica, 142(5), 381395.

Alifujiang, Y., Abuduwaili, J., Maihemuti, B., Emin, B., \& Groll, M. (2020). Innovative trend analysis of precipitation in the Lake Issyk-Kul Basin, Kyrgyzstan. Atmosphere, 11(4), 332.

Arslan, G., Kale, S., \& Sönmez, A. Y. (2020). Trend analysis and forecasting of the Gökırmak River streamflow (Turkey). Oceanological and Hydrobiological Studies, 49(3), 230-246. 
Ay, M., Karaca, Ö., \& Yıldız, A. (2018). Comparison of Mann-Kendall and Sen's innovative trend tests on measured monthly flows series of some streams in Euphrates-Tigris Basin. Erciyes Üniversitesi Fen Bilimleri Enstitüsü Fen Bilimleri Dergisi, 34(1), 78-86.

Aydin, H., Harlıoğlu, M. M., \& Bök, T. D. (2012). Harvest, export and economic status of freshwater crayfish (Astacus leptodactylus Esch.1823) in Turkey. African Journal of Agricultural Research, 7(16), 2463-2468.

Balık, İ., Çubuk, H., \& Uysal, R. (2003). Effect of bait on efficiency of fyke-nets for catching crayfish Astacus leptodactylus Esch. 1823. Turkish Journal of Fisheries and Aquatic Sciences, 3, 1-4.

Balik, İ., Çubuk, H., Özkök, R., \& Uysal, R. (2005). Some biological characteristics of crayfish (Astacus leptodactylus Eschscholtz, 1823) in Lake Eğirdir. Turkish Journal of Zoology, 29(4), 295-300.

Balık, İ., Özkök, E., \& Özkök, R. (2002). Catch per unit effort and size composition of crayfish, Astacus leptodactylus Eschscholtz 1823, in Lake İznik. Asian-Australasian Journal of Animal Sciences, 15(6), 884-889.

Balık, S., Ustaoğlu, M. R., Sarı, H. M., \& Berber, S. (2005). Determination of traits some growth and morphometric of crayfish (Astacus leptodactylus Eschscholtz, 1823) at Demirköprü (Manisa). Ege Journal of Fisheries and Aquatic Sciences, 22(1-2), 83-89.

Balık, S., Ustaoğlu, M. R., Sarı, H. M., \& Berber, S. (2006). Some reproduction properties of crayfish (Astacus leptodactylus Eschscholtz, 1823) in Demirköprü Dam Lake. Ege Journal of Fisheries and Aquatic Sciences, 23(3-4), 245-249.

Berber, S. (2020). Türkiye'de Kerevit Stoklarının Korunması ve Geliştirilmesi Önünde Engeller ve Çözüm Yolları. In A. Bolat (Ed.), Ziraat, Orman ve Su Ürünleri Alanında Akademik Çalışmalar - II (pp. 139-156). Ankara, Turkey: Gece Publishing.

Berber, S., \& Balık, S. (2006). Determination of traits some growth and morphometric of crayfish (Astacus leptodactylus Eschscholtz, 1823) at Manyas Lake (Balıkesir). Ege Journal of Fisheries and Aquatic Sciences, 23(1-2), 83-91.

Berber, S., \& Kale, S. (2018). Comparison of juvenile Astacus leptodactylus growth raised in cages in rice fields to other crayfish juvenile growth studies. Turkish Journal of Fisheries and Aquatic Sciences, 18(2), 331-341.

Berber, S., Kale, S., \& Türel, S. (2014). Ensuring the sustainability of crayfish stocks for fisheries management: Problems and solutions. Paper presented at the International Symposium on Fisheries and Aquatic Sciences: FABA 2014, Trabzon, Turkey. pp. 232.

Berber, S., Kale, S., Bulut, M., \& İzci, B. (2019). A study on determining the ideal stock density of freshwater crayfish (Pontastacus leptodactylus) in polyculture with rice (Oryza sativa L.). KSU Journal of Agriculture and Nature, 22(6), 953-964.

Berber, S., Mazlum, Y., Demirci, A., \& Türel, S. (2012). Structure, growth, mortality and size at sexual maturity of various populations Astacus leptodactylus Eschscholtz, 1823 (Cructacea: Decopada) in Turkey. Marine Science and Technology Bullettin, 1(1), 21-27.

Berber, S., Yildiz, H., Ateş, A.S., Bulut, M., \& Mendeş, M. (2010). A study on the relationships between some morphological and reproductive traits of the Turkish crayfish, Astacus leptodactylus Eschscholtz, 1823 (Crustacea: Decapoda). Reviews in Fisheries Science, 18(1), 131-137.

Bök, T., Aydın, H., \& Ateş, C. (2013). A study on some morphological characteristics of Astacus leptodactylus (Eschscholtz 1823) in seven different inland waters in Turkey. Journal of the Black Sea / Mediterranean Environment, 19(2), 190-205.

Bolat, Y. (2001). The Estimation of population size of freshwater crayfish (Astacus leptodactylus salimus Nordmann,1842) in Hoyran Part of Lake Eğirdir. (PhD), Süleyman Demirel University, Graduate School of Natural and Applied Sciences, Isparta, Turkey.

Bolat, Y., \& Kaya, M. A. (2016). Determination of growth and reproduction properties of freshwater crayfish (Astacus leptodactylus, Eschscholtz, 1823) in Eğirdir Lake-Turkey. Eğirdir Su Ürünleri Fakültesi Dergisi, 12(1), 11-24.

Bolat, Y., Demirci, A., \& Mazlum, Y. (2010). Size selectivity of traps (fyke-nets) of different mesh size on the narrow-clawed crayfish, Astacus leptodactylus (Eschscholtz, 1823) (Decapoda, Astacidae) in Eğirdir Lake, Turkey. Crustaceana, 83(11), 1349-1361. 
Cilbiz, M., Aydın, C. \& Uzunmehmetoğlu, O. Y. (2020). Türkiye'nin kerevit Pontastacus leptodactylus (Eschscholtz, 1823) üretiminin ulusal ve küresel ölçekte değerlendirilmesi LIMNOFISH-Journal of Limnology and Freshwater Fisheries Research, 6(1), 59-74.

Deveciyan, K. (2011). Türkiye'de Balık ve Balıkçılık. İstanbul, Turkey: Aras Yayıncılık. 574p.

Ejder, T., Kale, S., Acar, S., Hisar, O., \& Mutlu, F. (2016). Effects of climate change on annual streamflow of Kocabaş Stream (Çanakkale, Turkey). Journal of Scientific Research and Reports, 11(4), 1-11.

Ejder, T., Kale, S., Acar, S., Hisar, O., \& Mutlu, F. (2016). Restricted effects of climate change on annual streamflow of Sarıçay stream (Çanakkale, Turkey). Marine Science and Technology Bulletin, 5(1), 7-11.

Gedefaw, M., Yan, D., Wang, H., Qin, T. Girma, A., Abiyu, A., \& Batsuren, D. (2018). Innovative trend analysis of annual and seasonal rainfall variability in Amhara Regional State, Ethiopia. Atmosphere, 9(9), 326.

Gephart, J. A., Deutsch, L., Pace, M. L., Troell, M., \& Seekell, D. A. (2017). Shocks to fish production: Identification, trends, and consequences. Global Environmental Change, 42, 2434.

Harlioğlu, A. G., \& Harlioğlu, M. M. (2009). The status of freshwater crayfish (Astacus leptodactylus Eschscholtz) Fisheries in Turkey. Reviews in Fisheries Science, 17(2), 187-189.

Harlioğlu, M. M. (2004). The present situation of freshwater crayfish, Astacus leptodactylus (Eschscholtz, 1823) in Turkey. Aquaculture, 230(1-4), 181-187.

Harlioğlu, M. M. (2008). The harvest of the freshwater crayfish Astacus leptodactylus Eschscholtz in Turkey: Harvest history, impact of crayfish plague, and present distribution of harvested populations. Aquaculture International, 16(4), 351-360.

Harlığlu, M. M., \& Harlıoğlu, A. G. (2004). The harvest of freshwater crayfish, Astacus leptodactylus (Eschscholtz, 1823) in Turkey. Reviews in Fish Biology and Fisheries, 14(4), 415-419.

Harlığlu, M. M., Farhadi, A., \& Gür, S. (2018). Determination of sperm quality in decapod crustaceans. Aquaculture, 490, 185-193.

Harlioğlu, M. M., Kutluyer, F., \& Gür, S. (2012). An investigation on the sperm number and reproductive parameters of males in wild caught freshwater crayfish (Astacus leptodactylus, Eschscholtz). Animal Biology, 62(4), 409-418.

Kale, S. (2017a). Climatic trends in the temperature of Çanakkale city, Turkey. Natural and Engineering Sciences, 2(3), 14-27.

Kale, S. (2017b). Analysis of climatic trends in evaporation for Çanakkale (Turkey). Middle East Journal of Sciences, 3(2), 69-82.

Kale, S., \& Sönmez, A. Y. (2018a). Trend analysis of mean monthly, seasonally and annual streamflow of Daday Stream in Kastamonu, Turkey. Marine Science and Technology Bulletin, $7(2), 60-67$.

Kale, S., \& Sönmez, A. Y. (2018b). Trend analysis of streamflow of Akkaya Stream (Turkey). Paper presented at the 1st International Conference on Food, Agriculture and Animal Sciences, Antalya, Turkey. pp. 33-45.

Kale, S., \& Sönmez, A. Y. (2019a). Trend analysis for streamflow of Devrekani Stream (Turkey). Review of Hydrobiology, 12(1-2), 23-37.

Kale, S., \& Sönmez, A. Y. (2019b). Trend analysis for annual streamflow of Ilgaz Stream (Turkey). Paper presented at the 2nd International Congress on Engineering and Life Science, Kastamonu, Turkey. pp. 628-633.

Kale, S., \& Sönmez, A. Y. (2019c). Trend analysis for annual streamflow of Araç Stream (Turkey). Paper presented at the 2nd International Congress on Engineering and Life Science, Kastamonu, Turkey. pp. 746-753.

Kale, S., Berber, S., Acarlı, D., Demirkıran, T., Vural, P., Acarlı, S., Kizılkaya, B., \& Tan, E. (2020). First report of albinism in Turkish crayfish Pontastacus leptodactylus (Eschscholtz, 1823) (Crustacea, Decapoda, Astacidae). Acta Natura et Scientia, 1(1), 36-42.

Kale, S., Berber, S., Acarlı, D., Demirkıran, T., Vural, P., Acarlı, S., Kızılkaya, B., \& Tan, E. (2021). Blue color anomaly in Turkish crayfish Pontastacus leptodactylus (Eschscholtz, 1823) from 
Atikhisar Reservoir in Çanakkale, Turkey (Crustacea, Decapoda, Astacidae). Acta Natura et Scientia, 2(1), In press.

Kale, S., Ejder, T., Hisar, O., \& Mutlu, F. (2016). Climate change impacts on streamflow of Karamenderes River (Çanakkale, Turkey). Marine Science and Technology Bulletin, 5(2), 1-6.

Kale, S., Ejder, T., Hisar, O., \& Mutlu, F. (2016). Effect of climate change on annual streamflow of Bakırçay River. Adlyaman Üniversitesi Fen Bilimleri Dergisi, 6(2), 156-176.

Kale, S., Hisar, O., Sönmez, A. Y., Mutlu, F., \& Filho, W. L. (2018). An assessment of the effects of climate change on annual streamflow in rivers in Western Turkey. International Journal of Global Warming, 15(2), 190-211.

Karimpour, M., Harlioğlu, M. M., \& Aksu, Ö. (2011). Status of freshwater crayfish (Astacus leptodactylus) in Iran. Knowledge and Management of Aquatic Ecosystems, 401, 18.

Kişi, Ö., Guimaraes Santos, C. A., Marques da Silva, R. \& Zounemat-Kermani, M. (2018). Trend analysis of monthly streamflows using Şen's innovative trend method. Geofizika, 35(1), 5368.

Oladimeji, Y. U. (2017). Trend in fish production parameters in Nigeria and its total estimated demand: Empirical evidence from fish production. Journal of Animal Production Research, 29(1), 410-418.

Oladimeji, Y. U. (2018). Assessment of trend of artisanal fish production in Nigeria vis-a-vis implications on economic growth. Nigerian Journal of Fisheries and Aquaculture, 6(1), 3746.

R Core Team. (2020). R: A language and environment for statistical computing. $R$ Foundation for Statistical Computing, Vienna, Austria.

Sen, P. K. (1968). Estimates of the regression coefficient based on Kendall's Tau. Journal of the American Statistical Association, 63(324), 1379-1389.

Şen, Z. (2012). Innovative trend analysis methodology. Journal of Hydrologic Engineering, 17(9), 1042-1046.

Şen, Z. (2014). Trend identification simulation and application. Journal of Hydrologic Engineering, 19(3), 635-642.

Şen, Z. (2015). Innovative trend significance test and applications. Theoretical and Applied Climatology, 127, 939-947.

Şen, Z., Şişman, E., \& Dabanli, I. (2019). Innovative polygon trend analysis (IPTA) and applications. Journal of Hydrology, 575, 202-210.

Sönmez, A. Y., \& Kale, S. (2020). Climate change effects on annual streamflow of Filyos River (Turkey). Journal of Water and Climate Change, 11(2), 420-433.

Srivastava, S. K. (2004). Recent Trends in Production and Export of Fish in India and Status of Uttaranchal. Indian Journal of Agricultural Economics; 59(3), 509.

TurkStat. (2020). Fishery Statistics. https://biruni.tuik.gov.tr/medas/?kn=97\&locale=tr Access date: 30.04.2020.

Türel, S., Berber, S., \& Kale, S. (2014). The status and harvest of freshwater crayfish Astacus leptodactylus Eschscholtz 1823 in Turkey. Paper presented at the 5th International Symposium on Sustainable Development, Sarajevo, Bosnia and Herzegovina. pp. 137.

Yüksel, F., Demirol, F., \& Gündüz, F. (2013). Leslie population estimation for Turkish crayfish (Astacus leptodactylus Esch., 1823) in the Keban Dam Lake, Turkey. Turkish Journal of Fisheries and Aquatic Sciences, 13(5), 835-839. 